\begin{tabular}{|c|c|}
\hline \multirow{3}{*}{ 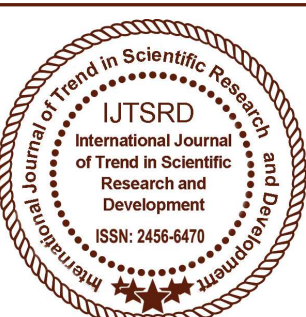 } & $\begin{array}{l}\text { International Journal of Trend in Scientific } \\
\text { Research and Development (IJTSRD) }\end{array}$ \\
\hline & International Open Access Journal \\
\hline & ISSN No: 2456 - 6470 | www.ijtsrd.com | Volume - 2 | Issue -3 \\
\hline
\end{tabular}

\title{
Mercuric Chloride Induced Oxidative Stress and Antioxidant Enzymes in Labeo Rohita as Biomarker
}

\author{
Kanaki. S ${ }^{1}$, Babu. $S^{1}$, Noorjahan. $A^{2}$ \\ ${ }^{1}$ Rajah Serfoji Government College (Autonoumous), Thanjavur, Tamil Nadu, India \\ ${ }^{2}$ Biofocus Research Centre, Thanjavur, Tamil Nadu, India
}

\section{ABSTRACT}

In recent years, heavy metal pollution has become a global environmental threat both ocean and inland fresh waste eco systems. Several aquatic systems were polluted by heavy metals from the industrial discharges. The discharges not only pollute the water bodies but also the aquatic plants, animals which related to human health issues. In the present study the fish Labeo rohita was exposed to three sub-lethal concentrations of Mercuric chloride which is nonessential metal and hazardous too, representing 5, 25 and $50 \%$ of $96 \mathrm{hr}$.LC50 respectively. The activity of antioxidant enzymes and oxidative stress due to the exposure of the heavy metal mercuric chloride induces [superoxide dismutase(SOD), catalase CAT), glutathione S.transeferase (GST)] SN and malondialdehyde (MDA) in the liver were investigated From the results it can be concluded that the activities and expression levels of antioxidant enzymes and oxidative stress can be used as biomarkers to evaluate the influence of heavy metal mercuric chloride as the biochemical pathway and enzymatic function in Labeo rohita that can be used for biological monitoring unacceptable levels of environmental contamination.

Keywords: Mercuric chloride, Labeo rohita ,SOD, CAT, GST, LPO

\section{INTRODUCTION}

Aquatic pollution is a major contributor to oxidative stress in fish, resulting from the redox cycling of pollution. Fish is an important aquatic organism. Fish products are an important source of protein for human consumption (Duran and Talas, 2009). Aquatic organisms can provide model systems for investigation of how reactive oxygen species (ROS) damage cellular compounds, how cells respond, how repair mechanisms reverse this damage, and how oxidative stress can lead to disease. Oxidative stress has become an important item for aquatic toxicology. Fish have been proposed as indicators for monitoring land-based pollution because they may concentrate indicative pollutants in their tissues directly from water through respiration and also through their diet. Fish are frequently subjected to pro-oxidant effects of different pollutants often present in the aquatic environment (Zikic, 2001,Matzinger et al., 2007; Vinodhini et al., 2009)

\section{Materials and Methods:}

In the present experiment, fish were divided into four groups in three replicates each group included 24 fish. Mercuric chloride of various concentration were added to the experimental glass aquaria one hour before the transfer of fish.

\section{Group 1: Exposed to 5\% (96 hrLC50)}

Group2: Exposed to 25\% (96 hr. LC50)

Group 3: Exposed to 50\% (96 hr.LC50)

Group 4: Served as a control.

Feeding was allowed in the experimental as well as control groups once per day.

\section{Experimental setup:}

At the end of exposure period (5, I5 and 30 days) 8 fish from each group were taken After dissection liver 
and gills tissues were carefully removed and washed with ice cold saline $(0.7 \mathrm{Nacl})$. The gill filaments were separated from the gill arches, weighed to the nearest $\mathrm{mg}$. Tissues (liver) were homogenized in 0.25 $\mathrm{M}$ sucrose buffer at $\mathrm{pH} 7.4$ using a glass homogenizer and then centrifuged at 8,000 rpm for $20 \mathrm{~min}$. The supernatant was used for enzymes assays.

\section{Enzymes assays}

\section{Super oxide dismutase (SOD)}

The activity of super oxide dismutase (SOD) in the liver tissues of the test fishes were determined spectrophotometrically at wave length $480 \mathrm{~nm}$ by epinephrine method Misra (1972) and expressed in units of enzymes activities per gram of tissues wet wt.

\section{Catalase activity (CAT)}

The activity of catalase CAT) in the liver were determined spectrophotometric at wave length $570 \mathrm{~nm}$ followed by the method of Sinha (1972) and was expressed in $\mathrm{ml} \mathrm{mol}$ of decomposed hydrogen peroxide per sec per gram of tissues wet wt.

\section{Glutathione S transferase (GST)}

The effect of glutathione S transferase (GST) was determined spectrophotometric at wave length $340 \mathrm{~nm}$ according to the method of Habig et al., (1974) using 1-chloro-2-4 dinitrobenzene (CDNB) as substrate. It was expressed in $\mu \mathrm{mol} / \mathrm{min} / \mathrm{mg}$ protein wet wt.

Malondialdehyde (MDA) was determined according to the method of Nair and Turner (1984). MDA derived from lipid peroxidation was determined with thiobarbituric acid (TBA). $0.5 \mathrm{ml}$ homogenate without filtration was taken and $4.5 \mathrm{ml}$ of TBA reagent was added. The mixture was heated using boiling water bath for $20 \mathrm{~min}$, centrifuged at $2500 \mathrm{rpm}$ for $10 \mathrm{~min}$. The absorbance of supernatant was recorded at wave length $525 \mathrm{~nm}$ MDA results were expressed as $\mu \mathrm{mol}$ of MDA per g. wet wt.in the tissues.

\section{Statistical analyses:}

All values were expressed as mean + standard error. The significance of difference between control and experimental data was statistically analyzed using student $\left.{ }^{(}(\mathrm{t})\right)$ test (Sendecor and Cochran, 1980).

\section{Results and Discussion:}

The oxidative stress due to mercuric chloride exposure of the fish shows changes in SOD, CAT, GST enzymes and lipid peroxidation (MDA) in the liver of Labeo rohita exposed to three sub-lethal concentrations $(5 \%, 25 \%$ and $50 \%)$ of Mercuric chloride were presented in (figures 1\&4). Changes was observed in SOD and CAT level of enzymes after 5 days of exposure to different concentrations of $\mathrm{HgCl}_{2}$. However after 15 and 30 days of exposure the activity of SOD was increased significantly to (30.1$38.3 \%)$ and $(26.7-48.1 \%), \mathrm{P}<0.05$. Similarly, CAT activity was increased significantly by (37.9-137\%) and $(65.6-188 \%)$ at low and high concentrations of Mercuric chloride. For GST the activity was significantly increase with the exposure concentration and duration time to (51-77\%), (90-184\%) and (103$207 \%$ ) for 5, 15 and 30 days respectively at 5\% to $25 \%$ of Mercuric chloride $(\mathrm{P}<0.05$ and 0.01$)$. No significant changes were observed in low dose of Mercuric chloride in MAD level of Labeo rohita. Moreover, there was a significant increase in MAD $(57.7-69 \%)(\mathrm{P}<0.01)$ at $25 \%$ and $50 \%$ concentration for 30 days of exposure.

Under normal physiological condition, the antioxidant defense enzymes including SOD, CAT and GST induced by a slight oxidative stress as a compensatory response, and thus the reactive oxygen species (ROS) can be removed to protect organisms from oxidative damage (living stone, 2001). The antioxidant activity may be provoked or inhibited under chemical stress depending on the intensity and duration of stress applied as well as susceptibility of exposure species. Fish liver is an organ that performs various functions associated with the metabolism of xenobiotics (Jiminez and Stegeman, 1990). Hepatocytes cells are dependent on antioxidant enzymes for the protection against reactive oxygen species produced during the bio transformation of xenobiotics (Londis and $\mathrm{Yu}$, 1995). The control values of superoxide dismutase (SOD) and catalase (CAT) enzymes activities in the liver of Labeo rohita ranged between (342 \pm 2.5 $361 \pm 1.4 \mathrm{unit} / \mathrm{g}$ wet wt.) and $(73 \pm 1.4-73 \pm 3.6 \mathrm{~m} \mathrm{~mol} / \mathrm{g}$ wet wt) respectively and were found to be within the same range compared with other water fishes (Oruce nd sta, 2007;Talas et al., 2008; Metwaly 2009;Wenju et al.,2009 and Gad and Yacoub 2009).The present study revealed that SOD and CAT activities in the liver of Labeo rohita exposed to Mercuric chloride were increased significantly $(\mathrm{P}<0.05$ and 0.01$)$.

Glutathione S transferase enzyme (GST) facilitates the conjugation of electrophilic substances or groups to tripeptide glutathione in order to make the xenobiotic chemicals more hydrophilic for transportation or excretion (Egaas et al., 1993).The control values of GST in the liver of Labeo rohita 
ranged between $0.96 \pm 0.02-1.0 \pm 0.8 \mu / \mathrm{mg}$ wet. wt of tissues were found to be within the normal range of freshwater fishes (Oruce and Usta 2007; Talas et al., 2008; Wenju et al., 2009 and Gad 2009). In the present study, GST showed time dependent elevation in the liver tissue of Labeo rohita exposed to Mercuric chloride with a significant provoke in the initial exposure and were doubled after 30 days of exposure.

The increase was also demonstrated after exposure of Labeo rohita fish to water soluble fraction of Mercuric chloride (Zang et al., 2004) Literatures are also found that the activity of detoxification enzymes such as GST increased in the presence of polycyclic aromatic hydrocarbon (Vander Oost et al.,2003). The increase in GST reported were indicated the biotransformation of pathway valid for Mercuric chloride used, as a protective response in fish toward exposure to an oxidative stress inducing xenobiotics. GST activity be a good biomarker for contamination environment. The increase in GST reported in the present study agrees with the results obtained in rainbow trout exposed to phenol (Uguz et al., 2003); in Atlantic cod exposed to sea oil and alkayl phenols for 15 days (Sturve et al.,2006).

Lipid peroxides are formed from the oxidative deterioration of poly unsaturated lipids in the membranes of cells and organelles. It is a bi-products, such as a malondialdehyde (MAD), are used as indicators for increased concentration of cellular reactive oxygen species and a sign of cellular injuries (Christi and Costa, 1984). Diverse contamination can initiate lipid peroxidation, including organic compounds and heavy metals. The control values of MDA in the liver of Labeo rohita ranged between $(51 \pm 3.2-53 \pm 2.6) \mu \mathrm{mol} / \mathrm{g}$ wet wt. and was found to be within the same range of other fresh water fishes ( Durmaz et al., 2006, Sturve et al.,2006 and Oruc and Usta 2007).

In the present study, there was no changes in lipid peroxidation level till 15 days of exposure to Mercuric chloride. We evolved MAD as a bi-product of lipid peroxidation after 30 days of exposure. The elevation in lipid peroxidation in the tissue of Labeo rohita indicated by increased MAD production which suggested the participation of free radical induced oxidative cell injury mediating the toxicity of Mercuric chloride. The result were correlated with the literature obtained in Atlantic cod exposed to sea oil and alkyl phenol for 15 days (Sturve et al., 2006); (Durmaz et al., (2006)

\section{Conclusion}

In conclusion this study demonstrated that crude oil at 5 to $25 \%$ concentration levels after 15 -30 days can cause adverse effects on Labeo rohita including the induction of SOD, CAT, GST and lipid peroxidation in the liver, The present results suggest that the activities and expression levels of antioxidant enzymes and oxidative stress can be used as biomarker to evaluate the influence of crude oil on the biochemical pathways and enzymatic function in the fish Labeo rohita so it can be used as a biological indicator to monitor unacceptable levels of environmental contamination.

\section{Reference:}

1) Abo-Hegab, S. K.; Marie,M. and Kandil, A. (1990).Change in plasma lipids and total protein of grass carp Ctenopharyngdone idella during environmental pollutant toxicity. Bullet. Zool. Soc. Egypt., 39:211- 222.

2) Christia, N. T.; and Costa, M. (1984). In vitro assessment of toxicity of metal compounds. IV,

3) Disposition of metals in cells:interaction with membranes, glutathione, metallothionine and DNA. Biol. Trace Elem. Res.,6:139-158.

4) Correia, A. D.; goncalves, R.; Scholze,M.; Ferreira,M.and Henrigues,M. A.(2007). Biochemical and behavioral responses in gill head seabream (Sperus auratus)to phenanthrene. J. Exper. Marine Boil \& Ecology., 347:109-122.

5) Duran, A., \& Talas, Z.S., Biochemical changes and sensory assessment on tissues of carp (Cyprinus carpio, Linnaeus, 1758) during sale conditions. Fish Physiol Biochem, 35, 709-714 (2009).

6) Durmaz, H.; Sevgiler,Y. and Uner, V. (2006). Tissues specific antioxidative and neurotoxic responses to diazinon in Oreochromis niloticus. Pestisid. Biochem.and Physio., 84: 215 -226

7) Egaas, E.; Skaare, J.U.; Svendesen, N.O.;Sandvik,M.; Falls, J.G.;Dauterman, W.C.; Collier,T.K. and Netland, J.(1993).A comparative study of effect of atrazine on xenobiotic metabolizing enzymes in fish and insect, and on the in vitro phase 11 atrazine metabolisms in some fish, insect, mammals and one plant species. Comp, Biochem. Physio., 106:141-149.

8) Gad, N. S. (2007).Assessment of some pesticides and heavy metals in water and fish of Oreochromis aureus from aquatic drainage and 
Nile canals and their impact on some biochemical parameters,J. Egypt. Ger. Soc. Zool.,53(A):325 346.

9) Matzinger a., Schmid m., Veljanoska-Sarafiloska e., Patceva s., Guseska d.,Muller b., Sturm m., wuest a. Eutrophication of ancient Lake Ohrid: Global warming amplifies detrimental effect of increased nutrient inputs. Limnol. Oceanogr. $52,(1), 338,2007$

10) Misra, H. P. (1972). The superoxide anion in antioxidation of epinephrine and simple assay for superoxide dismutase. J. Biol. Chem.,247: 31703175.

11) Nahragan, J.; Camus, L.; Gonzalez, P.; Jonsson,M.; Chritiansen, S.and Hop, H. (2010). Biomarker response in polar cod exposed to dietary crude oil. Aquatic Toxicol.96(1):77-83.

12) Oruc, E. O. and Usta, D. (2007). Evolution of oxidative stress responses and neuro toxicity potential of diazinon in different tissues of Cyprinus carpio. Environ. Toxicol. Pharm., 23: 48-55.

13) Sun, Y. Y.; Yu,H. X.; Zhang, J. F.; Yin, Y.;Shi, H. H. and Wang, X.R.(2006). Bioaccumulation, depuration and oxidative stress in fish Carassius auratus under phenanthrene Texposure. Chemosphere.,63:1319-1327.

14) Sturve, J.; Hasselberg, L.; Falth,H.;Celander, M.and Forlin, L. (2006). Effect of North sea oil and alkaylphenole on biomarker response in Juvenile Atlantic cod (Gadus morhua). Aquatic toxicology .,78: 73-78.

15) Simonata, J.; Guedes, C. and Martinez, C. (2008). Biochemical, physiological and histological changes in neotropical fish Prochildus lineatus exposed to diesel oil. Ecotoxicol. Environ. Saf 69:112-120 .

16) Sinha, A. K. (1972). Colorimetric assay of catalase, Analytical biochemistry 47:389-394.

17) Talas, Z.S.; Orun, I.; Ozdemir,L.; Erdogan, K.; Alkan, A. and Yilmaz, I.(2008). Antioxidative role of selenium against the toxic effect of heavy metals $(\mathrm{Cd}+2, \mathrm{Cr}+3)$ on liver of rainbow Trout (Oncorhnchus my kiss). Fish Physiol. Biochem.,34:217-222.

18) Halliwall, B. (1994). Free radicals and antioxidant A personal view. Nutr Rev. 52: 253-265.

19) Jiminez, B.D. and Stegeman, J. J. (1990). Detoxification enzymes as indicators of environmental stress on fish. Am. Fish. Soc. Symp. 8: 67-79.

20) Livingstoone, D. R.(2001).Contaminant stimulated reactive oxygen species production and oxidative damage in aquatic organisms. Mar. Pollution Bull.,42:656-666.

21) Londis, W. G. and Yu,M. H. (1995). Introduction toEnvironmental toxicology: Impacts of chemical upon Ecological system. Lewis Publishers, Boca Raton.

22) Uguz, C.; Iscan, M.; Erguven, A.; Isgor, B.; Togan, I.(2003). The bioaccumulation of nonylphenol and its adverse effect on the liver of Rainbow trout (Onchorynchus my kiss). Environ. Res.,92:262-270.

23) Vander

Oost,

R.;Beyer,J.andVermeulen,N.P.E.(2003). Fish bioaccumulation and biomarkers in Environmental risk assessment: a review. Environ.Toxicol. Pharmacol., 13:57-149.

24) Vinodhini $r$., Narayanan $m$. The impact of toxic heavy metals on the hematological parameters in common carp (Cyprinus carpio L.): Iran. J. Environ. Health. Sci.Eng., V. 6, (1), 23, 2009.

25) Wengu, X.; Yuangou,I.; Qingyang, W.; Shuqi, W.;Huaiping,Z.and Wenhua,L.(2009). Effect of phenanthrene on hepatic enzymatic activities in tilapia Oreochromis niloticus.J. Environ. Science 21:854-857.

26) Zang, J. F.; Shen, H.; Xu,T.L.;Wang,X. R.; Li,W.M. and Gu,Y.F.(2003). Effect of long term exposure of low level diesel oil on the antioxidant defense system of fish,Environ.Contam. Toxicol. 71: 234-239.

27) Zang, J. F.; Wang, X. R.; Guo, H.I.; Wu, J.C. and Xue, Y. Q.(2004). Effect of water soluble fraction of diesel oil on the antioxidant defense of the gold fish Carassius auratus, Ecotoxicol. Environ. Saf.,58 :110-116.

28) Zikic r. v., Stajn a. s., Pavlovic s. z.,Ognanovic b. i., Saicic z. s. Activities of Superoxide Dismutase and Catalase in Erithrocytes and Plasma Transaminases of Goldfish (Carassius auratus gibelio Bloch.) Exposed to Cadmium. Physiol. Res., 50,105, 2001. 


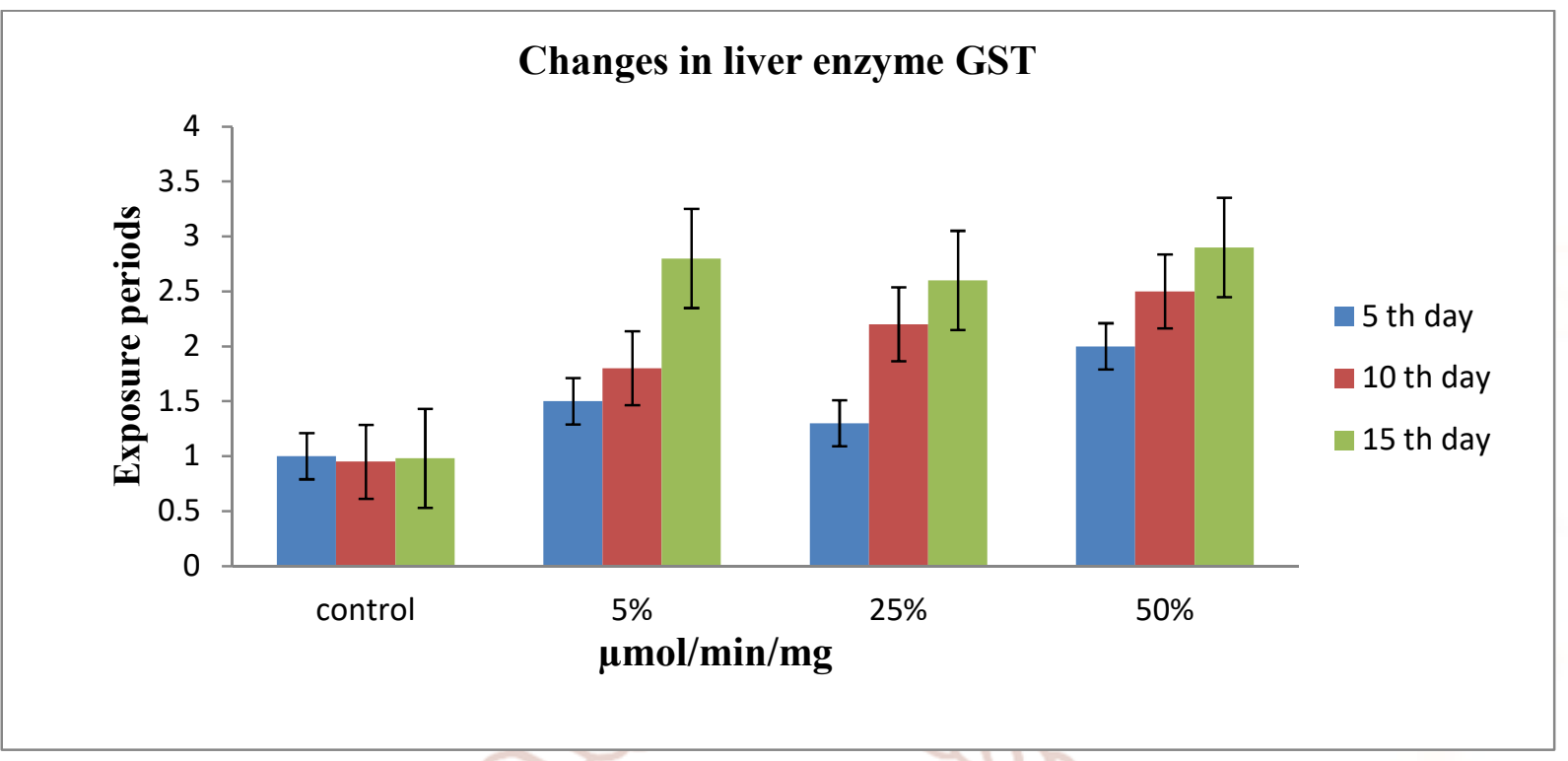

1.1 The oxidative stress due to mercuric chloride exposure of the fish shows changes in GST

\section{Enzymes Changes in LPO}

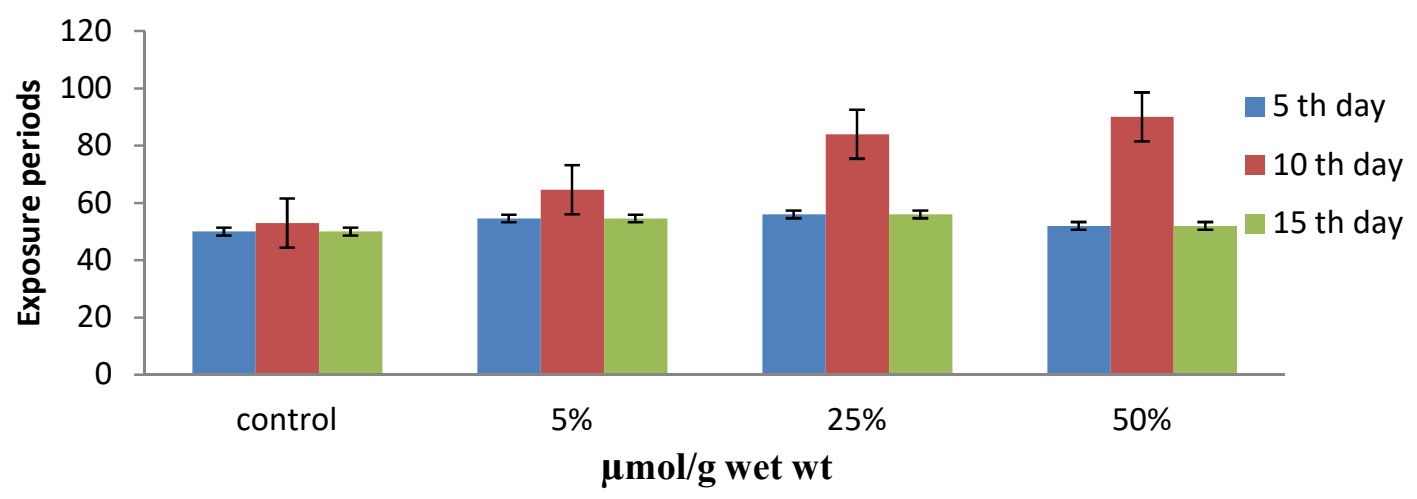

1.2. The oxidative stress due to mercuric chloride exposure of the fish shows changes in LPO

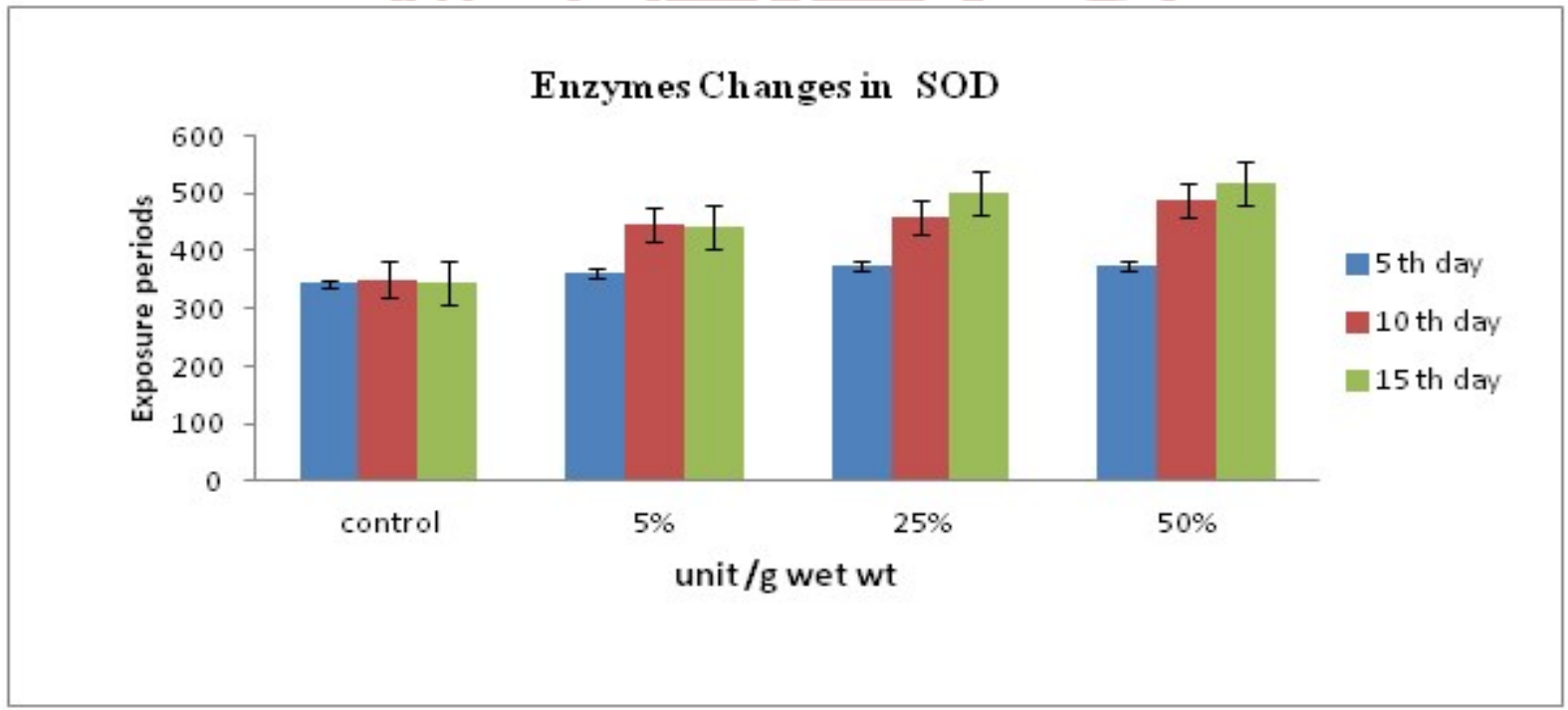

1.3. The oxidative stress due to mercuric chloride exposure of the fish shows changes in SOD 
International Journal of Trend in Scientific Research and Development (IJTSRD) ISSN: 2456-6470

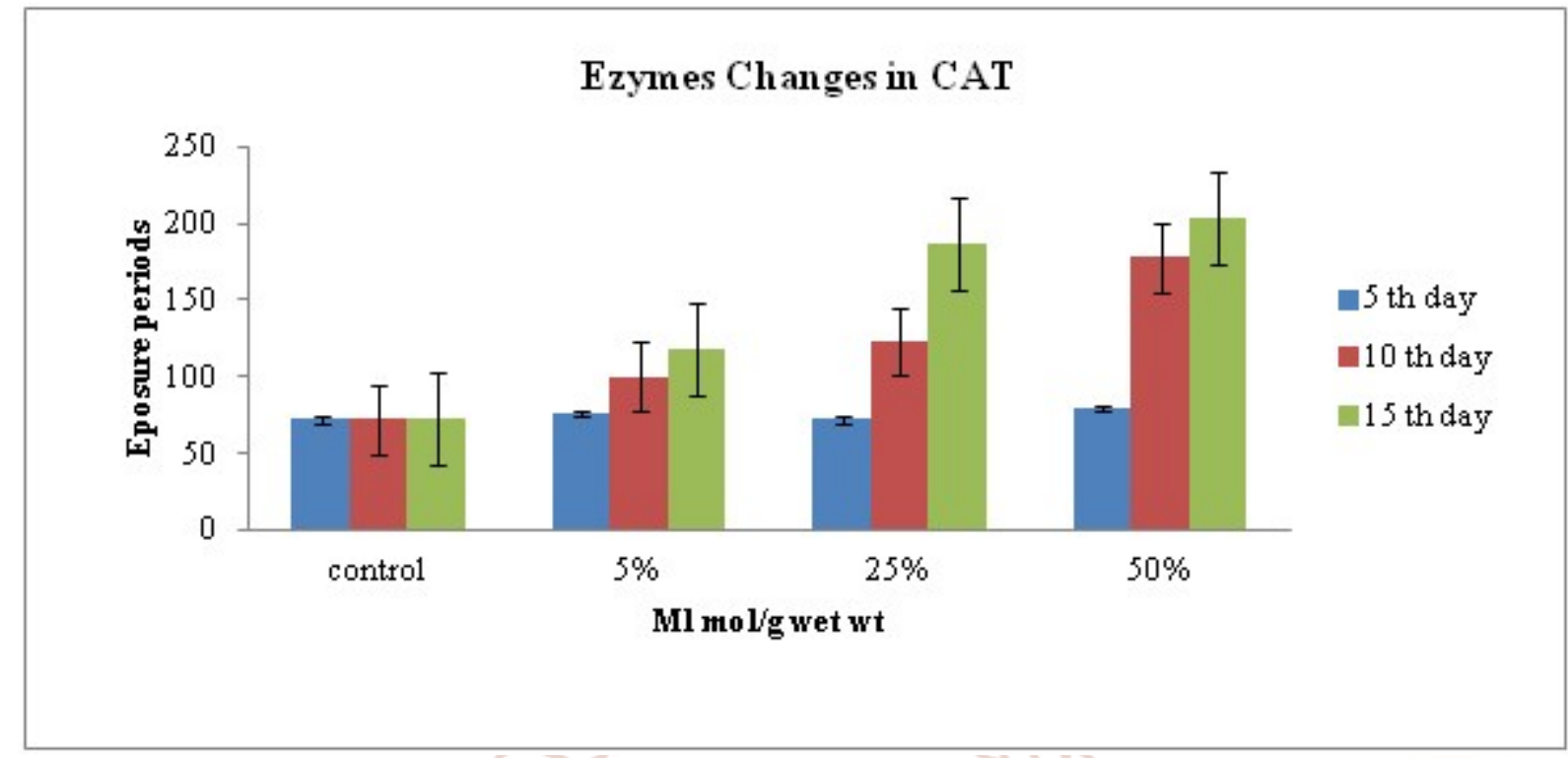

1.4. The oxidative stress due to mercuric chloride exposure of the fish shows changes in CAT

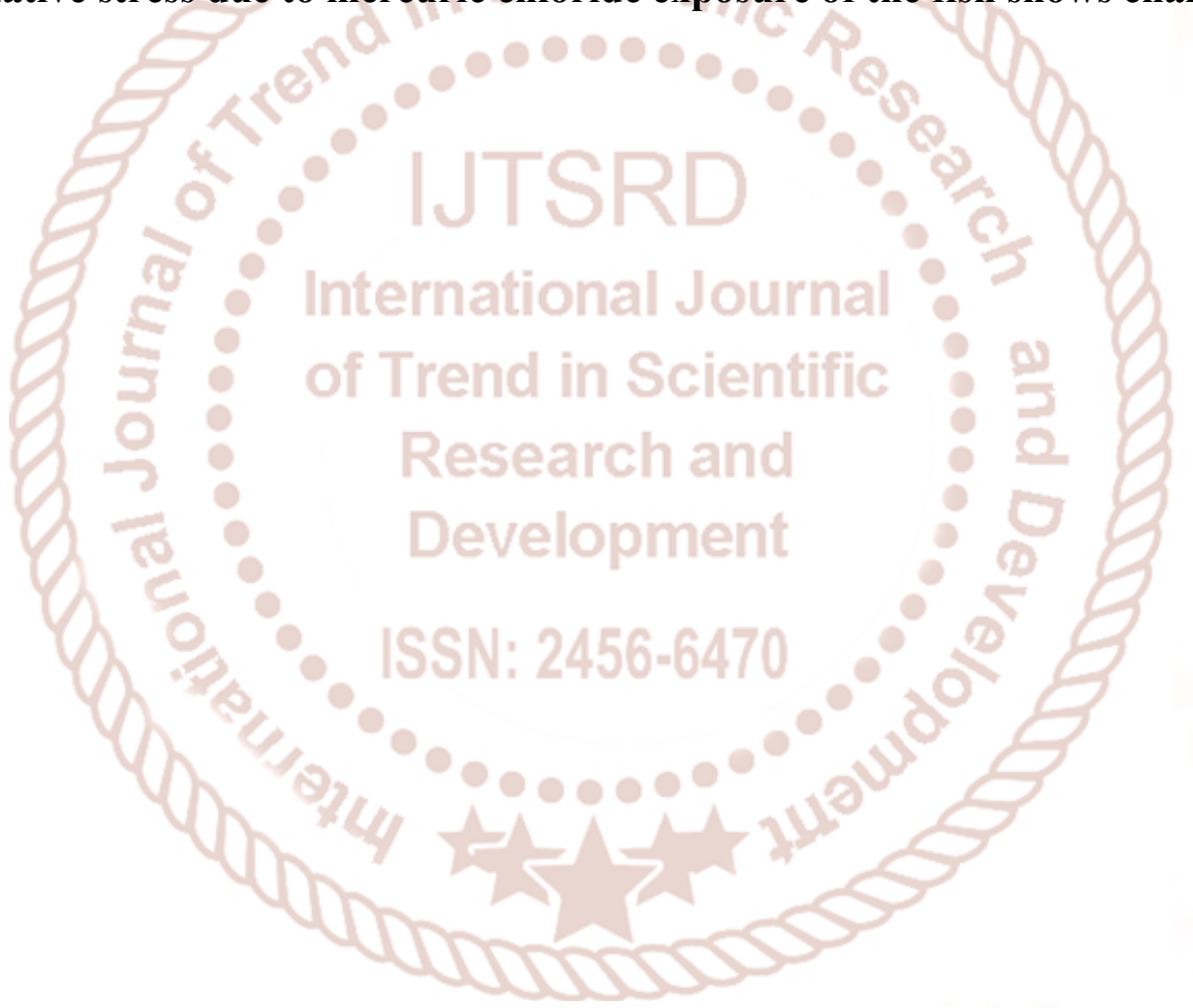

